\title{
Noradrenergic Suppression of Persistent Firing in Hippocampal CA1 Pyramidal Cells through cAMP- PKA Pathway
}

\author{
Maria Jesus Valero-Aracama, ${ }^{1, *}$ Antonio Reboreda, ${ }^{2,3, *}$ Alberto Arboit, ${ }^{2}$ Magdalena Sauvage, ${ }^{3,4,5}$ and \\ Motoharu Yoshida ${ }^{1,2,3,5}$
}

https://doi.org/10.1523/ENEURO.0440-20.2020

${ }^{1}$ Faculty of Psychology, Mercator Research Group-Structure of Memory, Ruhr-University Bochum, Bochum 44780, Germany, ${ }^{2}$ German Center for Neurodegenerative Diseases (DZNE), Magdeburg 39120, Germany, ${ }^{3}$ Leibniz Institute for Neurobiology (LIN), Magdeburg 39118, Germany, ${ }^{4}$ Otto von Guericke University, Functional Neuroplasticity, Medical Faculty, Magdeburg 39120, Germany, and ${ }^{5}$ Center for Behavioral Brain Sciences (CBBS), 39106, Magdeburg, Germany

\begin{abstract}
Persistent firing is believed to be a cellular correlate of working memory. While the effects of noradrenaline (NA) on working memory have widely been described, its effect on the cellular mechanisms of persistent firing remains largely unknown. Using in vitro intracellular recordings, we demonstrate that persistent firing is supported by individual neurons in hippocampal CA1 pyramidal cells through cholinergic receptor activation, but is dramatically attenuated by NA. In contrast to the classical theory that recurrent synaptic excitation supports persistent firing, suppression of persistent firing by NA was independent of synaptic transmission, indicating that the mechanism is intrinsic to individual cells. In agreement with detrimental effects of cAMP on working memory, we demonstrate that the suppressive effect of NA was through cAMP-PKA pathway. In addition, activation of $\beta 1$ and/or $\beta 3$ adrenergic receptors, which increases cAMP levels, suppressed persistent firing. These results are in line with working memory decline observed during high levels of NA and cAMP, which are implicated in high stress, aging, and schizophrenia.
\end{abstract}

Key words: $\beta 1$ adrenoceptors; cAMP; M1 receptor; M2/4 receptors; persistent firing; PKA

\section{Significance Statement}

While cholinergic modulation supports working memory, high concentrations of noradrenaline (NA), which occurs under high stress for example, are detrimental for working memory. However, cellular and molecular mechanisms underlying such working memory deficit remain largely unclear. In this paper, we studied the effect of these two neuromodulators on persistent firing, the cellular correlate of working memory. We demonstrate that a cholinergic receptor activation supports, while a noradrenergic activation strongly inhibits persistent firing because of the PKA activation through specific NA receptor types which upregulate cAMP. These data are in line with working memory deficits in aging and schizophrenia in which cAMP levels are altered, and indicate potential intrinsic cellular mechanism of working memory impairment.

\section{Introduction}

Persistent firing is a cellular response characterized by repetitive spiking that outlasts triggering stimulus, and is believed to be a neural base of working memory (Goldman-

Received October 12, 2020; accepted December 20, 2020; First published February 26, 2021.

The authors declare no competing financial interests.
Rakic, 1995; Major and Tank, 2004). Persistent firing observed in humans and animals in vivo during working memory tasks correlate with the task performance (Funahashi et al., 1989; Colombo and Gross, 1994; Hampson and Deadwyler, 2003;

Author contributions: M.J.V.-A., A.R., M.S., and M.Y. designed research; M.J.V.-A., A.R., and A.A. performed research; M.J.V.-A., A.R., and A.A. analyzed data; M.J.V.-A., A.R., and M.Y. wrote the paper. 
Bukalo et al., 2004; Kamiński et al., 2017). In contrast to the classical hypothesis that persistent firing is supported by recurrent excitatory synaptic connections, recent studies have shown that persistent firing can also be supported in individual cells (Egorov et al., 2002; Jochems and Yoshida, 2013; Knauer et al., 2013). These studies in general used cholinergic receptor activations to induce persistent firing, which is in agreement with the supportive role of acetylcholine on working memory (Reboreda et al., 2018). However, roles of other neuromodulators such as the noradrenaline (NA) on this type of persistent firing largely remain to be studied.

While cholinergic modulation generally supports working memory (Kaneko and Thompson, 1997; Weiss et al., 2000), NA could be detrimental for working memory (Arnsten, 2009; Roozendaal and McGaugh, 2011). High levels of NA are usually present during states of stress (Bremner et al., 1996), which are known to impair working memory (Diamond et al., 1996; Schoofs et al., 2008; Qin et al., 2009; Arnsten et al., 2012). At the receptor subtype levels, $\beta 1$ and $\alpha 2$ adrenoreceptors, which are positively and negatively coupled to CAMP signaling, impair and facilitate working memory, respectively (Jäkälä et al., 1999; $\mathrm{Li}$ et al., 1999; Ma et al., 2003; Arnsten and Li, 2005; Ramos et al., 2005). In addition, elevated and decreased cAMP levels impair and enhance, respectively, working memory performance (Arnsten et al., 1999; Taylor et al., 1999; Runyan et al., 2005; Wang et al., 2007). Moreover, upregulated CAMP levels are associated with working memory impairment in aging and schizophrenia (Millar, 2005; Wang et al., 2011; Barch and Ceaser, 2012). Raising cAMP levels would increase PKA activation that also is negatively correlated to working memory performance (Kobori et al., 2015), together supporting the importance of NA and CAMP-PKA in working memory.

At the cellular level, a supportive role of NA on persistent firing through a reduction of CAMP levels has been observed in the prefrontal cortex (PFC; Zhang et al., 2013). In addition, elevated cAMP levels caused a suppression of the calcium-activated nonspecific cation (CAN) current and persistent firing in the PFC and hippocampus (Sidiropoulou et al., 2009; El-Hassar et al., 2011; Zhang et al., 2013). However, it remains unclear whether NA has a supportive or detrimental effect on persistent firing in the hippocampus.

We therefore tested the effects of cholinergic and noradrenergic receptor activation in both induction and

This work was supported by the Mercator Stiftung and by German Research Foundation (DFG) Project Grants YO177/4-1 and YO177/7-1.

${ }^{*}$ M.J.V.-A. and A.R. contributed equally to this work.

M. J. Valero-Aracama's present address: Institute of Physiology and Pathophysiology, Friedrich-Alexander-Universität Erlangen-Nürnberg, Erlangen, 91054, Germany.

Acknowledgements: We thank Dr. Menno Witter for kindly sharing experimental procedures with us.

Correspondence should be addressed to Motoharu Yoshida at motoharu. yoshida@lin-magdeburg.de.

https://doi.org/10.1523/ENEURO.0440-20.2020

Copyright (C) 2021 Valero-Aracama et al.

This is an open-access article distributed under the terms of the Creative Commons Attribution 4.0 International license, which permits unrestricted use, distribution and reproduction in any medium provided that the original work is properly attributed. modulation of persistent firing in individual hippocampal CA1 pyramidal cells in mice. We find that a noradrenergic stimulation strongly inhibits persistent firing while a cholinergic activation supports it. In addition, the noradrenergic suppression of persistent firing is independent of ionotropic synaptic transmission, but is through the CAMP-PKA pathway. We further demonstrate specific NA receptor subtypes involved in this suppression. These observations indicate that high NA and CAMP conditions, which often suppress working memory through PKA activation, also suppress cellular mechanisms for persistent firing in the hippocampus.

\section{Materials and Methods}

All the experimental designs were approved by the local ethic committee (Der Tierschutzbeauftragte, Ruhr-Universität Bochum, and Deutsches Zentrum für Neurodegenerative Erkrankungen) and conducted in accordance with the European Communities Council Directive of September 22, 2010 (2010/63/EU).

\section{Slice preparation}

Acute hippocampal slices were obtained from adult (two to four months) C57BL6 female mice (Charles River). Animals were deeply anesthetized (intraperitoneal injection of $120 \mathrm{mg} / \mathrm{kg}$ of ketamine and $16 \mathrm{mg} / \mathrm{kg}$ of xylazin) and intracardiac perfusion with ice-cold modified artificial CSF (mACSF) was conducted directly without or after cervical dislocation. The mACSF contained $87 \mathrm{~mm} \mathrm{NaCl}, 25$ mm $\mathrm{NaHCO}_{3}, 10 \mathrm{~mm}$ glucose, $75 \mathrm{~mm}$ sucrose, $2.5 \mathrm{~mm} \mathrm{KCl}$, $1.25 \mathrm{~mm} \mathrm{NaH}_{2} \mathrm{PO}_{4}, 0.375 \mathrm{~mm} \mathrm{CaCl}_{2}, 3.28 \mathrm{~mm} \mathrm{MgCl}_{2}, 3$ $\mathrm{mm}$ pyruvix acid, and $1 \mathrm{~mm}$ ascorbic acid or $87 \mathrm{~mm} \mathrm{NaCl}$, $25 \mathrm{~mm} \mathrm{NaHCO}_{3}, 10 \mathrm{~mm}$ glucose, $75 \mathrm{~mm}$ sucrose, $1.25 \mathrm{~mm}$ $\mathrm{KCl}, 1.25 \mathrm{~mm} \mathrm{NaH}_{2} \mathrm{PO}_{4}, 0.188 \mathrm{~mm} \mathrm{CaCl}_{2}, 1.64 \mathrm{~mm} \mathrm{MgCl}_{2}$, $3 \mathrm{~mm}$ pyruvix acid, and $1 \mathrm{~mm}$ ascorbic acid (pH was adjusted to 7.4 by saturation with $95 \% \quad \mathrm{O}_{2}-5 \% \quad \mathrm{CO}_{2}$ ). Following the decapitation, horizontal hippocampal slices (350 $\mu \mathrm{M})$ were obtained with a vibrating-blade microtome (Leica VT1000S) in ice-cold mACSF. Brain slices were then incubated for $30 \mathrm{~min}$ at $37^{\circ} \mathrm{C}$ in normal ACSF (nACSF) containing $124 \mathrm{~mm} \mathrm{NaCl}, 1.25 \mathrm{~mm} \mathrm{NaH}_{2} \mathrm{PO}_{4}, 1.8$ $\mathrm{mm} \mathrm{MgO}_{4} \mathrm{~S}, 3 \mathrm{~mm} \mathrm{KCL}, 10 \mathrm{~mm}$ glucose, $26 \mathrm{~mm} \mathrm{NaHCO}_{3}$, and $1.2 \mathrm{~mm} \mathrm{CaCl}_{2}$ or $124 \mathrm{~mm} \mathrm{NaCl}, 1.25 \mathrm{~mm} \mathrm{NaH}_{2} \mathrm{PO}_{4}, 1.8$ $\mathrm{mm} \mathrm{MgO}_{4} \mathrm{~S}, 1.5 \mathrm{~mm} \mathrm{KCL}, 10 \mathrm{~mm}$ glucose, $26 \mathrm{~mm} \mathrm{NaHCO}_{3}$, and $0.6 \mathrm{mM} \mathrm{CaCl}_{2}(\mathrm{pH}$ was adjusted to 7.4 by saturation with $\left.95 \% \mathrm{O}_{2}-5 \% \mathrm{CO}_{2}\right)$. The second nACSF with $1.5 \mathrm{~mm}$ $\mathrm{KCL}$ was used in an attempt to reduce synaptic effect but was used only in seven cells in which ICl-118,551 was applied. In all other 105 cells, the first nACSF with $3 \mathrm{~mm} \mathrm{KCL}$ was used. Brain slices were maintained at room temperature for at least $30 \mathrm{~min}$ before recording.

\section{Whole-cell recordings}

Whole-cell procedures were performed as described previously (Valero-Aracama et al., 2015). Briefly, CA1 cells were visually identified using an upright microscope (Zeiss Axioskop 2FS), and whole-cell patch was obtained using glass pipettes filled with an intracellular solution containing 120 mm Kgluc, 10 mm HEPES, 0.2 mm EGTA, 
$20 \mathrm{~mm} \mathrm{KCl}, 2 \mathrm{~mm} \mathrm{MgCl}_{2}, 7 \mathrm{~mm}$ PhCreat di(tris), $4 \mathrm{~mm}$ $\mathrm{Na}_{2}$ ATP, and $0.3 \mathrm{~mm}$ Tris GTP ( $\mathrm{pH}$ adjusted to 7.3 with $\mathrm{KOH})$. Electrical signals were amplified with an Axoclamp 2A amplifier (Molecular Devices), low-pass filtered at $10 \mathrm{kHz}$ and sampled at $20 \mathrm{kHz}$, using WinWCP (John Dempster, University of Strathclyde) software. Liquid junction potential ( $\sim 10 \mathrm{mV})$ was not corrected. To prevent pharmachological contamination, only one cell per slice was recorded. Recordings were performed at $34 \pm 1^{\circ} \mathrm{C}$.

\section{Drugs}

All drugs except for carbachol (Cch; Alfa Aesar) were purchased from Sigma-Aldrich. Water-based stock solutions were made for all drugs except picrotoxin and kynurenic acid (freshly dissolved in nACSF). Except for the Cch stock solution, which was stored at $4^{\circ} \mathrm{C}$, all other solutions were aliquoted and stored at $-20^{\circ} \mathrm{C}$. Stock solutions were diluted at least 1000 times in the final solution. Recording solutions with Cch were freshly made each day of experiment and solutions containing other drugs were freshly made from stock solutions minutes before being used. Recordings started at least $5 \mathrm{~min}$ after the application of the experimental drug.

\section{Data analysis}

Analysis was conducted with MATLAB R2009b (MathWorks) and Anaconda (Python 3.6). Only pyramidal cells with a silent resting membrane potential lower than $-55 \mathrm{mV}$, and spike amplitudes that overshoot $0 \mathrm{mV}$ were included into the analysis. Persistent firing was induced by a current injection ( $2 \mathrm{~s}, 100 \mathrm{pA})$ from a membrane potential below spiking threshold. The membrane potential and frequency of persistent firing were measured during the first 10 s after the termination of the stimulation. General excitability was measured from the current-frequency curve (50-350 pA, 50-pA increment, $1 \mathrm{~s})$ starting from the fix potential of $-65 \mathrm{mV}$. Input resistance (IR) was computed from the voltage drop peak in response to a 50-pA negative current injection from $-65 \mathrm{mV}$. Sag ratio was computed from voltage response to a negative current step (1 s, $-300 \mathrm{pA})$. Medium and slow after-hyperpolarizing potential (AHP) were measured after the induction of six spikes (0.1$1 \mathrm{nA}, 3 \mathrm{~ms}, 50 \mathrm{~Hz}$ ) from a membrane potential of $-60 \mathrm{mV}$. In cases the AHP was positive compared with the baseline (as in conditions with Cch) this property is referred to as ADP. Comparisons were made using paired $t$ tests. Significance level $\alpha<0.05\left({ }^{*} p<0.05,{ }^{* \star} p<0.01,{ }^{* \star *} p<\right.$ 0.001 ) was used. Data are expressed as mean \pm SEM.

\section{Results}

\section{Cch supports persistent firing through $G_{q / 11}$ and $G_{i / o}$ G-protein-coupled receptors (GPCRs)}

First, we tested the effects of cholinergic stimulation alone on the generation of persistent firing in CA1 pyramidal cells. Once a whole-cell recording was obtained, induction of persistent firing was tested by using a brief $(2 \mathrm{~s}$, $100 \mathrm{pA}$ ) current injection at a membrane potential right below the spike threshold. In the nACSF, none of the cells tested continued spiking after the termination of the stimulation ( $n=34$; Fig. $1 A$, left). However, in the presence of Cch $(5 \mu \mathrm{M})$, persistent firing was induced in $62 \%$ (21 out of 34) of the same set of cells (Fig. 1A, right). This is in agreement with previous reports of similar persistent firing in rat and mouse CA1 pyramidal cells in Cch (Knauer et al., 2013; Arboit et al., 2020). For the quantification of persistent firing, spike frequency and membrane potential after the stimulation were measured: poststimulus frequency and poststimulus potential. The gray line below each voltage trace indicates the period during which these measurements were taken. Cch significantly increased the poststimulus frequency $\left(n=34 ; T_{(33)}=-5.65, p<0.001\right.$; Fig. $1 B$, left) and the poststimulus membrane potential $\left(n=34 ; T_{(33)}=-6.67, p<0.001\right.$; Fig. $1 B$, right $)$.

Cch activates both $\mathrm{G}_{\mathrm{q} / 11}$ and $\mathrm{G}_{\mathrm{i} / \mathrm{o}}$ GPCRs through M1 and $M 2 / 4$ receptor subtypes, respectively. To study the role of each receptor subtype on persistent firing, we selectively blocked M1 or M2/4 receptors. Bath application of the $\mathrm{M} 1$ antagonist pirenzepine $(10 \mu \mathrm{M})$, in addition to Cch, resulted in a complete blockade of persistent firing (Fig. $1 C, D)$. The poststimulus frequency $\left(n=5 ; T_{(4)}=5.94\right.$, $p<0.01$; Fig. $1 D$, left) and depolarization $\left(n=5 ; T_{(4)}=\right.$ 7.10, $p<0.01$; Fig. $1 D$, right) were significantly reduced. Similarly to this, M2/4 antagonist himbacine $(1 \mu \mathrm{M})$ suppressed persistent firing significantly (Fig. 1E) reducing both the frequency $\left(n=6 ; T_{(5)}=6.59, p<0.01\right.$; Fig. $1 F$, left $)$ and the depolarization $\left(n=6 ; T_{(5)}=7.83, p<0.001\right.$; Fig. $1 F$, right). These results point out that both $\mathrm{G}_{\mathrm{q} / 11}$-coupled and $\mathrm{G}_{\mathrm{i} / \mathrm{o}}$-coupled receptors are necessary to trigger persistent firing. Furthermore, a control experiment was conducted to exclude the possibility that the suppressive effect of pirenzepine and himbacine was because of a run-down of cellular mechanisms supporting persistent firing during the wholecell recording. In this experiment, persistent firing recorded at two different time points after the break-in was compared in the presence of Cch. The first and second time points were comparable to the times at which persistent firing was tested in Cch alone and Cch + pirenzepine (or himbacine), respectively, in the above experiment. Persistent firing was not reduced, as shown in Figure 1G,H (frequency: $n=8$, $T_{(7)}=0.388, \quad p=0.709 ;$ potential: $n=8, \quad T_{(7)}=0.730$, $p=0.489$ ), indicating that the suppression of persistent firing was not an artifact of our experimental procedure.

\section{NA does not support persistent firing}

We next tested the effects of NA $(5-10 \mu \mathrm{m} ; n=14)$ on the induction of persistent firing. Persistent firing was not observed in any of the cells recorded and the poststimulus firing frequency was unchanged (Fig. 2A). While the poststimulus membrane hyperpolarization (AHP) was reduced by $\mathrm{NA}\left(n=14 ; T_{(13)}=-3.068, p=0.009\right.$; Fig. $\left.2 C\right)$, the membrane potential did not reach levels above the baseline (averaged voltage before the stimulation) unlike Cch.

It has been reported that intrinsic excitability of CA1 pyramidal cells is increased by both cholinergic and noradrenergic modulation (Benardo and Prince, 1982; Madison and Nicoll, 1982). In agreement with these, the numbers of spikes elicited during the stimulation (2 s, $100 \mathrm{pA})$ were significantly larger in both Cch and NA compared with those in the nACSF (Cch: nACSF $23 \pm 1$, Cch $31 \pm 2$, 
A

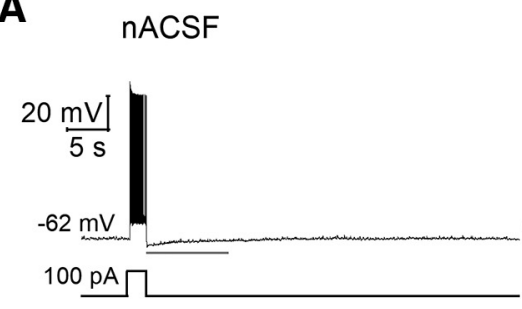

$-64 \mathrm{mV}$

Cch

C

Cch

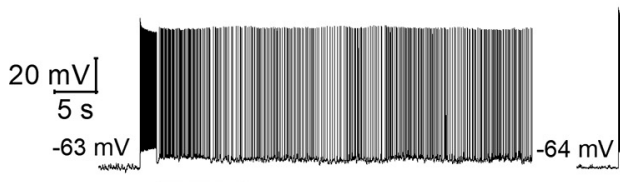

Cch + Pirenzepine

E Cch

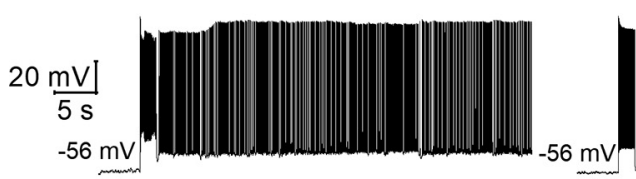

Cch + Himbacine

G

Cch

Cch

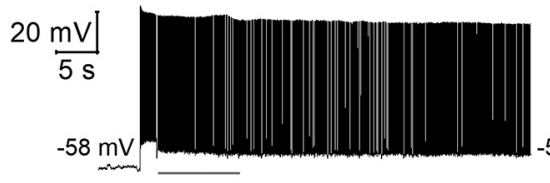

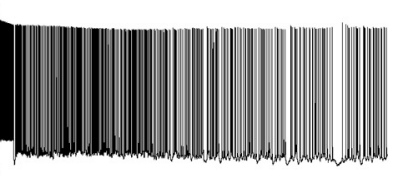

$几$
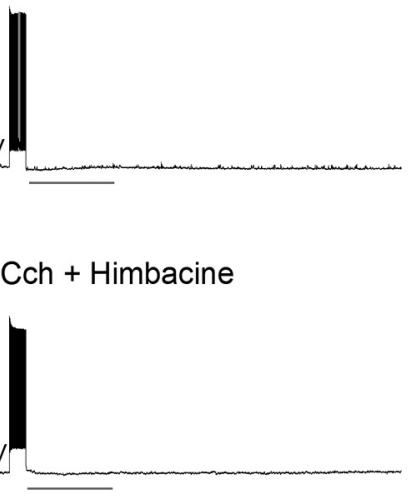

B

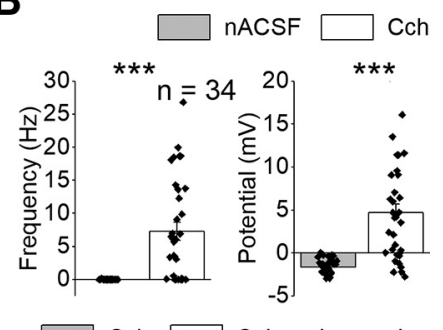

D

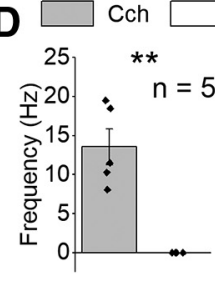

Cch + pirenzepine

$\mathbf{F}$

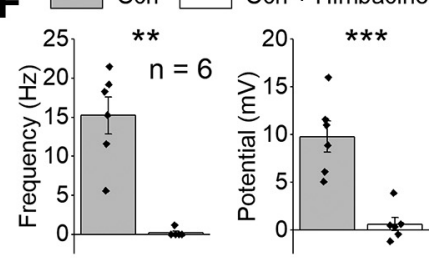

H

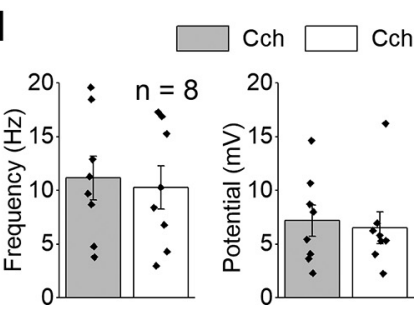

Figure 1. Cholinergic induction of persistent firing in CA1 hippocampal neurons. $\boldsymbol{A}$, Representative cell's responses in nACSF (left) and in Cch (right). The gray line indicates the 10-s period in which characteristics of persistent firing were analyzed. Trace at the bottom shows the current step applied to test persistent firing. B. Poststimulus frequency (left) and poststimulus potential (right) in nACSF (gray) and Cch (white). C, Representative trace of the effect of muscarinic M1 antagonist pirenzepine on the cholinergic persistent firing. $\boldsymbol{D}$, Poststimulus frequency (left) and poststimulus potential (right) in Cch (gray) and Cch and pirenzepine (white). $\boldsymbol{E}$, Representative trace of the effect of muscarinic M2/M4 antagonist himbacine on the cholinergic persistent firing. $\boldsymbol{F}$, Poststimulus frequency (left) and poststimulus potential (right) in Cch (gray) and Cch and himbacine (white). $\boldsymbol{G}$, Representative responses from timed control experiment. $\boldsymbol{H}$, Poststimulus frequency (left) and poststimulus potential (right) in the first test in Cch (gray) and the second test in Cch (white).

$n=34, T_{(33)}=-4.69, p<0.001 ; \mathrm{NA}: \mathrm{nACSF} 21 \pm 1$, NA $\left.28 \pm 2, n=14, T_{(13)}=-4.77, p<0.001\right)$. A reduced AHP mentioned above is also in agreement with the previous report (Madison and Nicoll, 1982), while the mAHP measured after five spikes (Table 1) did not show significant decrease probably because of a bad signal-to-noise ratio.

These indicate that persistent firing was not simply the result of increased excitability because persistent firing was observed only in Cch. This is in line with the specific role of the CAN current in support of persistent firing, which is activated downstream of the cholinergic receptor (Yan et al., 2009; Zhang et al., 2011; Knauer et al., 2013). Changes of other basic properties by Cch and NA are listed in the Table 1.

\section{Effect of NA on cholinergically-induced persistent firing}

Based on the observation that NA alone did not support the induction of persistent firing, we next tested whether
NA has modulatory effects on persistent firing under cholinergic activation. In this experiment, persistent firing was tested first in $\mathrm{nACSF}$, then in Cch $(5 \mu \mathrm{M})$, and finally in a solution containing $\mathrm{Cch}$ and NA $(5-10 \mu \mathrm{M})$. To ensure a full effect of NA, persistent firing was tested $\sim 15$ min after the initiation of the NA application. In ten neurons that showed persistent firing in Cch condition, persistent firing was completely blocked in six, suppressed in three, and slightly increased in one cell by NA (Fig. 2B). Poststimulus firing frequency and membrane potential were both significantly decreased by NA (frequency: $n=12, T_{(11)}=4.118$, $p=0.002$; potential: $n=12, T_{(11)}=5.647, p<0.001$; Fig. $2 D, E)$. Cells that did not exhibit persistent firing in Cch did not show it in NA either ( $n=3$; data not shown).

Next, to assess whether the reduction of persistent firing was synaptic or intrinsic, the effect of NA on cholinergically induced persistent firing was examined in the presence of synaptic blockers (SBs) that blocked the 
A

nACSF

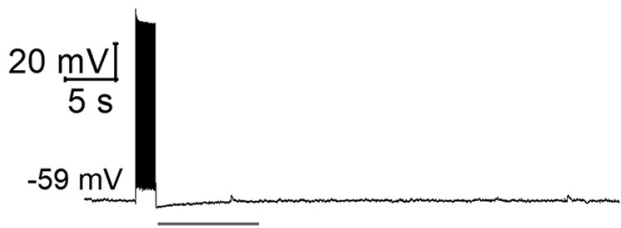

B

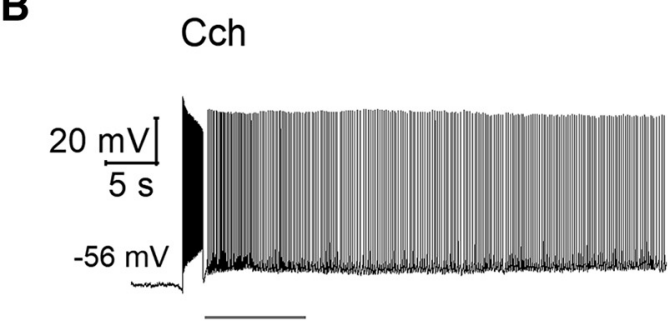

NA

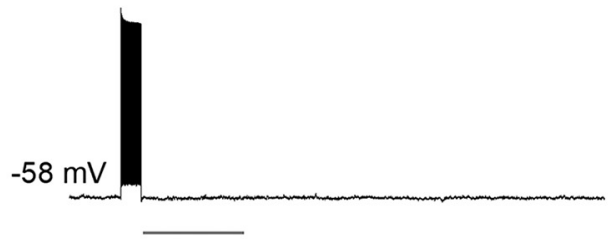

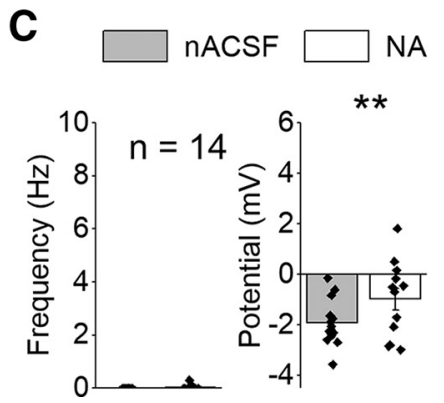
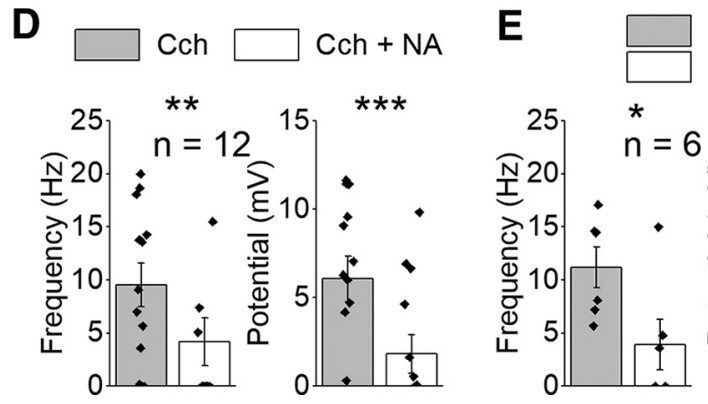

$\operatorname{Cch}(\mathrm{SB})$

$\mathrm{Cch}+\mathrm{NA}(\mathrm{SB})$

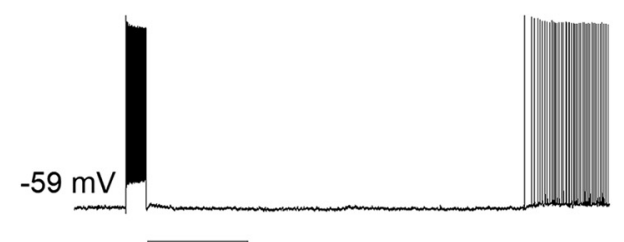

Figure 2. NA suppresses persistent firing. $\boldsymbol{A}$, Representative traces of the effect of NA in nACSF. $\boldsymbol{B}$, Representative traces of the effect of NA on the cholinergic persistent firing. $\boldsymbol{C}$, Effect of NA on poststimulus frequency (left) and poststimulus potential (right) without Cch. $\boldsymbol{D}$, Same as in $\boldsymbol{C}$ but in Cch. $\boldsymbol{E}$, Same as in $\boldsymbol{D}$ but in the presence of the SBs.

ionotropic excitatory and inhibitory transmissions $(0.1 \mathrm{~mm}$ picrotoxin and $2 \mathrm{~mm}$ kynurenic acid). In line with our previous study in rat CA1 pyramidal cells (Knauer et al., 2013), induction of persistent firing was not affected by the presence of the SBs, indicating that persistent firing is supported by intrinsic cellular mechanisms (data not shown). As for the modulation of persistent firing, an application of NA suppressed persistent firing significantly similarly to the case without SBs (frequency: $n=6, T_{(5)}=3.748$, $p=0.013$; potential: $n=6 ; T_{(5)}=-6.016, p=0.002$; Fig. $2 E)$. Together, these data indicate that suppression of persistent firing was probably caused by other mechanisms than a potential change in synaptic transmission because of NA. Changes of other basic properties by NA in the presence of Cch are listed in the Table 2.

\section{Intracellular mechanisms underlying the suppression of persistent firing}

Cholinergic and noradrenergic systems act through different receptors coupled to mainly three types of GPCRs. While Ach activates only $\mathrm{G}_{\mathrm{q} / 11}(\mathrm{M} 1, \mathrm{M} 3, \mathrm{M} 5)$ and $\mathrm{G}_{\mathrm{i} / \mathrm{o}}(\mathrm{M} 2$, M4) pathways, NA can activate $\mathrm{G}_{\mathrm{s}}(\beta 1, \beta 2, \beta 3)$ in addition to $\mathrm{G}_{\mathrm{q} / 11}(\alpha 1)$ and $\mathrm{G}_{\mathrm{i} / \mathrm{o}}(\alpha 2$, partially $\beta 2)$ pathways. The $\mathrm{G}_{\mathrm{s}}$ pathway, unlike other two pathways, increases the cAMP level, which is detrimental to working memory
(Dash et al., 2007). In addition, an elevated cAMP level has been shown to suppress persistent firing in vivo in the PFC, and suppresses the CAN current in the hippocampus as mentioned above (El-Hassar et al., 2011). Therefore, we tested whether NA suppressed persistent firing by a cAMP activation through the $\mathrm{G}_{\mathrm{s}}$ pathway.

First, we evaluated the effect of an elevated cAMP concentration on persistent firing using forskolin, a compound that activates the adenylate cyclase and therefore increases intracellular levels of cAMP. Persistent firing was first tested in Cch $(5 \mu \mathrm{M})$ and then forskolin $(10 \mu \mathrm{M})$ was bath applied in addition to Cch. This and other experiments in this section were conducted in the presence of SBs. Forskolin clearly suppressed persistent firing (frequency: $n=8, T_{(7)}=8.165, p<0.001$; potential: $n=8$, $T_{(7)}=8.165, p<0.001$; Fig. $\left.3 A, B\right)$. We found that forskolin also decreased the number of spikes during the stimulation (Cch: $23.56 \pm 1.5$; Cch+forskolin: $19 \pm 1.8 ; n=8$; $\left.T_{(7)}=3.789, p=0.007\right)$. To study whether the suppression of persistent firing was simply because of the smaller number of spikes elicited during the stimulation, response of the cells to a fixed number (six) of induced spikes were additionally tested (Fig. $3 C$ ). Spikes were induced by using six brief current injections $(0.1-1 \mathrm{nA}, 3 \mathrm{~ms}, 50 \mathrm{~Hz})$ at $-60 \mathrm{mV}$, and the poststimulus potential was measured as 
Table 1: Effect of Cch and NA on general cellular properties

\begin{tabular}{|c|c|c|c|c|c|c|c|c|}
\hline \multicolumn{9}{|l|}{ Part I } \\
\hline & & $50 \mathrm{pA}$ & $100 \mathrm{pA}$ & $150 \mathrm{pA}$ & $200 \mathrm{pA}$ & $250 \mathrm{pA}$ & $300 \mathrm{pA}$ & $350 \mathrm{pA}$ \\
\hline nACSF & $n=47$ & $1 \pm 0$ & $11 \pm 2$ & $21 \pm 2$ & $31 \pm 2$ & $37 \pm 2$ & $42 \pm 2$ & $46 \pm 2$ \\
\hline Cch & & $6 \pm 2^{\star \star}$ & $23 \pm 2^{\star \star \star}$ & $35 \pm 2^{\star \star \star}$ & $41 \pm 2^{\star \star \star}$ & $46 \pm 2^{\star \star \star}$ & $49 \pm 2^{\star \star \star}$ & $53 \pm 3^{\star *}$ \\
\hline NA & & $2 \pm 1$ & $12 \pm 3^{*}$ & $23 \pm 4^{\star \star}$ & $31 \pm 4^{\star \star}$ & $36 \pm 4^{\star *}$ & & \\
\hline
\end{tabular}

Part II

\begin{tabular}{|c|c|c|c|c|c|c|c|c|c|c|}
\hline & \multicolumn{2}{|c|}{ IR $(\mathrm{M} \Omega)$} & \multicolumn{2}{|r|}{$\mathrm{TH}(\mathrm{mV})$} & \multicolumn{2}{|r|}{ SAG } & \multirow{2}{*}{\multicolumn{2}{|c|}{$\mathrm{mAHP}(\mathrm{mV})$}} & \multicolumn{2}{|c|}{$\mathrm{ADP}(\mathrm{mV})$} \\
\hline & $n$ & & $n$ & & $n$ & & & & $n$ & \\
\hline nACSF & 48 & $105 \pm 4$ & 51 & $-47.9 \pm 0.6$ & 48 & $0.166 \pm 0.01$ & 42 & $-1.16 \pm 0.11$ & 42 & $-0.27 \pm 0.07$ \\
\hline Cch & & $139 \pm 6^{\star \star \star}$ & & $-48.9 \pm 0.7^{\star \star}$ & & $0.151 \pm 0.01$ & & $-0.26 \pm 0.14^{\star \star \star}$ & & $1.24 \pm 0.15^{\star \star \star}$ \\
\hline nACSF & 15 & $90 \pm 6$ & 9 & $-46.4 \pm 2.0$ & 15 & $0.173 \pm 0.01$ & 9 & $-1.47 \pm 0.34$ & 9 & $-0.40 \pm 0.25$ \\
\hline NA & & $115 \pm 8^{\star \star \star}$ & & $-47.3 \pm 1.8$ & & $0.115 \pm 0.01^{\star *}$ & & $-1.33 \pm 0.27$ & & $0.23 \pm 0.13^{\star}$ \\
\hline
\end{tabular}

Part I, Number of spikes elicited by 1-s current steps. Part II, Input resistance (IR), spike threshold (TH), sag ratio (SAG), medium AHP (mAHP), after depolarizing potential (ADP). Values correspond to mean \pm SEM. Significance level: ${ }^{\star} p<0.05,{ }^{* \star} p<0.01,{ }^{* \star *} p<0.001$

an average membrane depolarization during the 2-s period after the simulation offset (gray line). The poststimulus potential was significantly smaller in the $\mathrm{Cch}+$ forskolin condition compared with that in Cch alone $\left(n=7 ; T_{(6)}=4.803\right.$, $p=0.003$; Fig. 4C), suggesting that the suppression of persistent firing by forskolin was not simply because of the reduced number of spikes triggered during the stimulation.

The fact that forskolin is able to suppress persistent firing might be indicating that NA suppression could be generated by an increase of cAMP that leads to PKA activation. To test this hypothesis, we included the competitive PKA antagonist Rp-cAMPS $(100 \mu \mathrm{M})$ in the recording pipette. In this condition, NA mediated inhibition of persistent firing was strongly reduced ( $n=10$; Fig. $4 A$ ). Figure $4 B$ shows the effect of NA on the frequency and depolarization of persistent firing with and without RpcAMPS. Rp-cAMPS prevented the suppressive effect of NA on persistent firing, maintaining persistent firing similar to that in the control condition without NA (Fig. 4B). A multiple comparison with a two-way repeated-measures ANOVA followed by pairwise comparisons with the Tukey's post hoc test indicated that neither the frequency or depolarization changed significantly when Rp-cAMPS was present (the third and fourth columns), while both were reduced significantly by NA when Rp-cAMPS was not present (the first and second columns). In contrast, when persistent firing in NA was compared with or without Rp-cAMPS (the second and fourth columns), both frequency and depolarization were significantly larger when Rp-cAMPS was present (frequency: $t_{(20)}=4.104, p=$ 0.040 ; potential: $t_{(20)}=8.932, p<0.001$; Fig. $\left.4 B\right)$. These indicate that suppression of persistent firing by NA is mainly by $\mathrm{G}_{\mathrm{s}}$ activation of PKA.

As a control experiment, we repeated the forskolin application in the presence of Rp-cAMPS (Fig. 4C). Repeated-measures two-way ANOVA coupled with the Tukey's post hoc test indicated that forskolin inhibition of persistent firing was strongly reduced in the presence of Rp-cAMPS (frequency: $t_{(13)}=3.164, p=0.164$; potential: $t_{(13)}=1.321, p=0.787$; Fig. $4 D$, third and fourth columns). In contrast, Rp-cAMPS had a significant effect on the frequency and depolarization in the presence of forskolin (frequency: $t_{(13)}=5.903, p=0.005$; potential: $t_{(13)}=5.660$, $p=0.007$; Fig. $4 D$, second and fourth column). These indicate that the suppressive effect of forskolin was through PKA activation.

Experiments with forskolin and Rp-cAMPS supported the idea that NA interfered with persistent firing through a cAMP mediated activation of PKA. To further demonstrate the involvement of receptor subtypes coupled to the $G_{s}$ pathway, effects of individual receptor agonists were tested. First, the effect of the $\alpha 2$ receptor agonist clonidine $(10 \mu \mathrm{M})$, which decreases cAMP levels through $\mathrm{G}_{\mathrm{i} / \mathrm{o}}$ activation, was examined in the presence of Cch. As expected, clonidine did not inhibit persistent firing (frequency: $n=10, T_{(9)}=-0.646, p=0.534$; potential: $n=10$;

Table 2: Effect of NA on top of Cch on general cellular properties

\begin{tabular}{|c|c|c|c|c|c|c|c|c|}
\hline \multicolumn{9}{|l|}{ Part I } \\
\hline & & $50 \mathrm{pA}$ & $100 \mathrm{pA}$ & $150 \mathrm{pA}$ & $200 \mathrm{pA}$ & $250 \mathrm{pA}$ & $300 \mathrm{pA}$ & $350 \mathrm{pA}$ \\
\hline$\overline{\mathrm{Cch}}$ & $n=13$ & $6 \pm 3$ & $26 \pm 4$ & $37 \pm 3$ & $41 \pm 3$ & $47 \pm 3$ & $50 \pm 3$ & $53 \pm 3$ \\
\hline $\mathrm{Cch}+\mathrm{NA}$ & $19 \pm 5$ & $29 \pm 5$ & $42 \pm 4$ & $48 \pm 4$ & $54 \pm 5$ & $57 \pm 6$ & $60 \pm 5$ & \\
\hline
\end{tabular}

Part II

\begin{tabular}{|c|c|c|c|c|c|c|}
\hline & & $\mathrm{IR}(\mathrm{M} \Omega)$ & $\mathrm{TH}(\mathrm{mV})$ & SAG & mAHP (mV) & $\mathrm{ADP}(\mathrm{mV})$ \\
\hline$\overline{\text { Cch }}$ & $n=13$ & $142 \pm 11$ & $-51.0 \pm 1.6$ & $0.147 \pm 0.02$ & $-0.14 \pm 0.29$ & $1.28 \pm 0.26$ \\
\hline $\mathrm{Cch}+\mathrm{NA}$ & $129 \pm 10^{*}$ & $-53.7 \pm 1.6$ & $0.145 \pm 0.01$ & $-0.27 \pm 0.22$ & $0.84 \pm 0.12$ & \\
\hline
\end{tabular}

Part I, Number of spikes elicited by 1-s current steps. Part II, Input resistance (IR), spike threshold (TH), sag ratio (SAG), medium AHP (mAHP), after depolarizing potential (ADP). Values correspond to mean \pm SEM. 


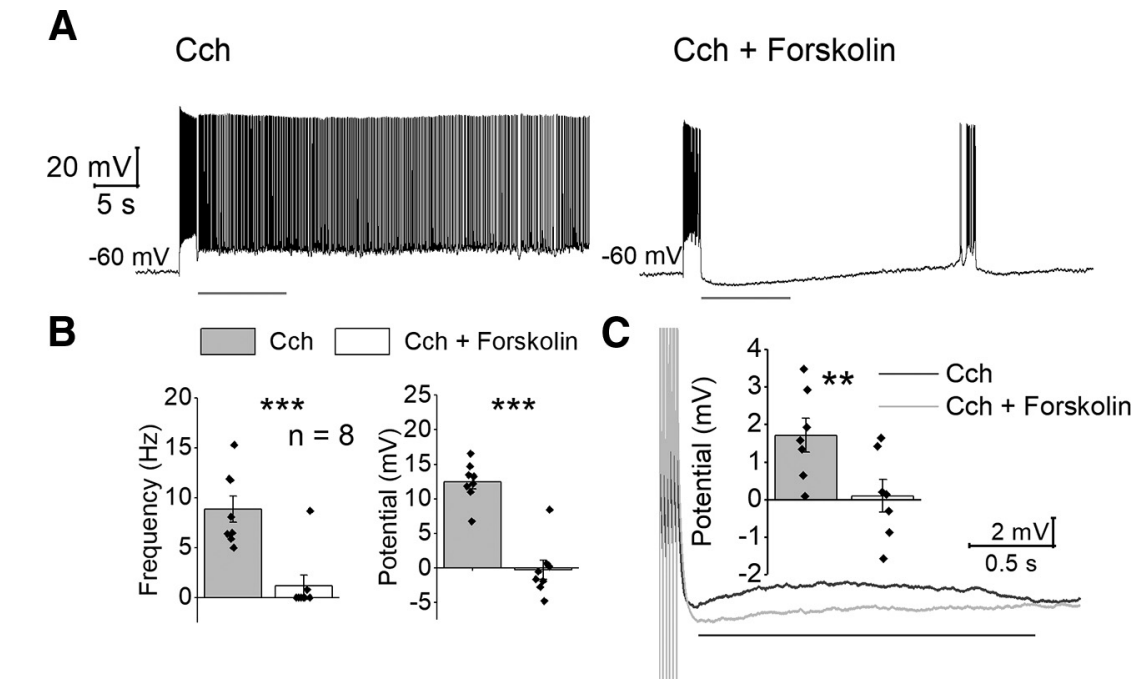

Cch + Forskolin

Figure 3. Forskolin suppresses persistent firing. $\boldsymbol{A}$, Representative traces of the inhibition by forskolin on the cholinergic persistent firing. $\boldsymbol{B}$, Poststimulus frequency (left) and poststimulus potential (right) in Cch (gray) and Cch+forskolin (white). $\boldsymbol{C}$, Representative after depolarization following six spikes in Cch (gray) and in a cocktail containing Cch and forskolin (gray). Gray straight line indicates the section analyzed. Vertical lines under truncated spikes indicate the timing of current injection. The bar graph shows the membrane potential in Cch (gray) and Cch+forskolin (white).

$T_{(9)}=1.234, p=0.252 ;$ Fig. $\left.5 A, B\right)$. As for the adrenergic $\beta$ receptors, although all $\beta$ receptors $(\beta 1, \beta 2, \beta 3)$ are coupled to $\mathrm{G}_{\mathrm{s}}$, recent studies pointed out that $\beta 2$ activates the $G_{i}$ in addition to the $G_{s}$ cascade (Hall, 2004; Schutsky et al., 2011a,b). Therefore, we aimed to activate $\beta 1$ and $\beta 3$ receptors without activating $\beta 2$ by using the general $\beta$ receptor agonist isoproterenol (ISO; $1 \mu \mathrm{m}$ ) along with the $\beta 2$ blocker ICl-118,551 (ICl; $1 \mu \mathrm{M}$ ) based on a previous report (Schutsky et al., 2011a). Combination of ISO and ICI significantly inhibited persistent firing (frequency: $n=7$, $T_{(6)}=4.634, p=0.004$; potential: $n=7, T_{(6)}=4.488, p=0.004$; Fig. $5 C, D)$. In contrast, a sole application of the general $\beta$ agonist ISO did not affect persistent firing either at $1 \mu \mathrm{M}$ (frequency: $n=7, T_{(6)}=1.788, p=0.124$; potential: $n=7, T_{(6)}=$ $0.777, p=0.467$ ) or at $10 \mu \mathrm{M}$ (frequency: $n=8, T_{(7)}=0.008$, $p=0.994$; potential: $n=8, T_{(7)}=0.729, p=0.128$; Fig. $5 E, F$ ), indicating that, in line with previous literature, $\beta 2$ might induce actions that counteract the increase of cAMP. In summary, these results suggest that NA suppresses cholinergically-induced persistent firing via PKA activation downstream of a $\beta 1$ and/or $\beta 3$ receptors mediated increase of cAMP.

\section{Discussion}

Based on the differential modulation of working memory by acetylcholine and NA, we investigated effects of these neuromodulators on the induction and modulation of persistent firing in hippocampal CA1 pyramidal cells in brain slices taken from adult female mice. Results from this study indicate that only the cholinergic agonist Cch, but not NA, is able to support induction of persistent firing. However, when NA was applied in addition to Cch, NA strongly suppressed cholinergically triggered persistent firing. We have further shown that the suppression of persistent firing by NA was not a result of decreased intrinsic excitability or ionotropic synaptic transmissions. In contrast, forskolin, the specific activation of $\beta 1$ and PKA blockade with Rp-cAMPS indicated that cAMP elevations through the $\mathrm{G}_{\mathrm{s}}$-protein cascade activating PKA caused the suppression of the cholinergic persistent firing.

\section{Molecular mechanisms underlying suppression of persistent firing}

Persistent firing similar to our study is shown to be supported by intrinsic cellular mechanisms in multiple brain areas involved in working memory (Fraser and MacVicar, 1996; Haj-Dahmane and Andrade, 1998; Egorov et al., 2002; Tahvildari et al., 2008; Navaroli et al., 2012; Jochems and Yoshida, 2013; Knauer et al., 2013). These studies have pointed out that this type of persistent firing is supported by the CAN current, which is believed to be supported by TRPC channels (Reboreda et al., 2011; Zhang et al., 2011; Arboit et al., 2020). In line with our data, the CAN current and TRPC channels are inhibited by the cAMP (Partridge et al., 1990; El-Hassar et al., 2011; Sung et al., 2011). In particular, El-Hassar et al. (2011) used forskolin in the hippocampal CA1 pyramidal cells as in our study to indicate that TRPC mediated CAN current is suppressed. Suppression of similar persistent firing by cAMP was also reported in the entorhinal cortex and PFC (Sidiropoulou et al., 2009; Zhang et al., 2013). Therefore, CAN current suppression is a feasible mechanism for the suppression of persistent firing in our study.

However, it is possible that other mechanisms were additionally involved. One possibility could be that an increase in GABAergic input mediated by NA (Kawaguchi and Shindou, 1998; Sessler et al.,, 1995) suppressed persistent firing. Inhibitory synaptic input is known to be higher in the presence of NA (Kawaguchi and Shindou, 1998; Sessler et al., 1995). Inhibitory synaptic input is effective in terminating persistent firing in the dentate gyrus 
A

Cch (Rp)

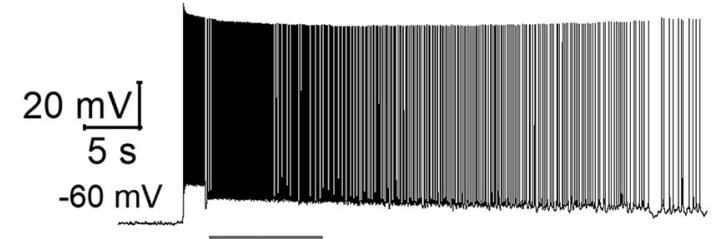

B

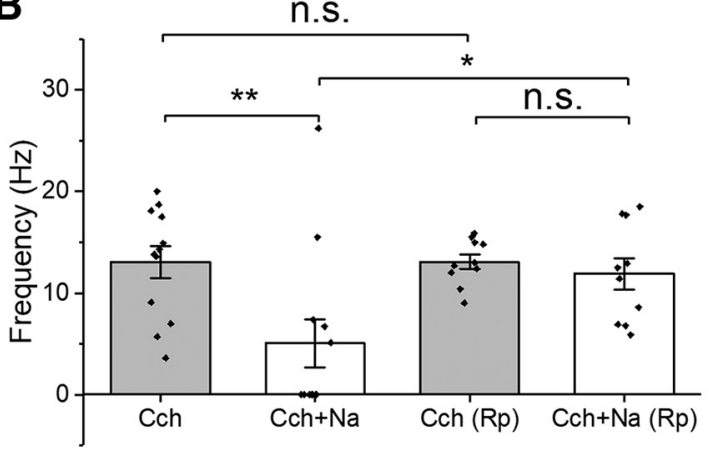

C

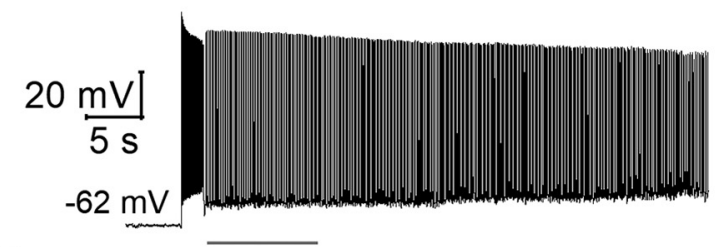

D

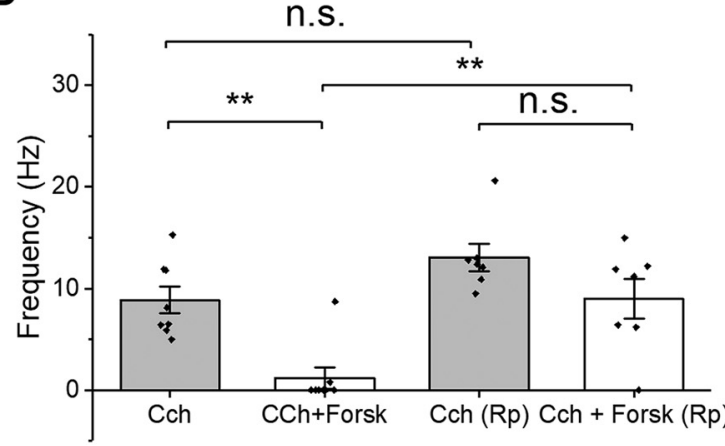

Cch + NA (Rp)
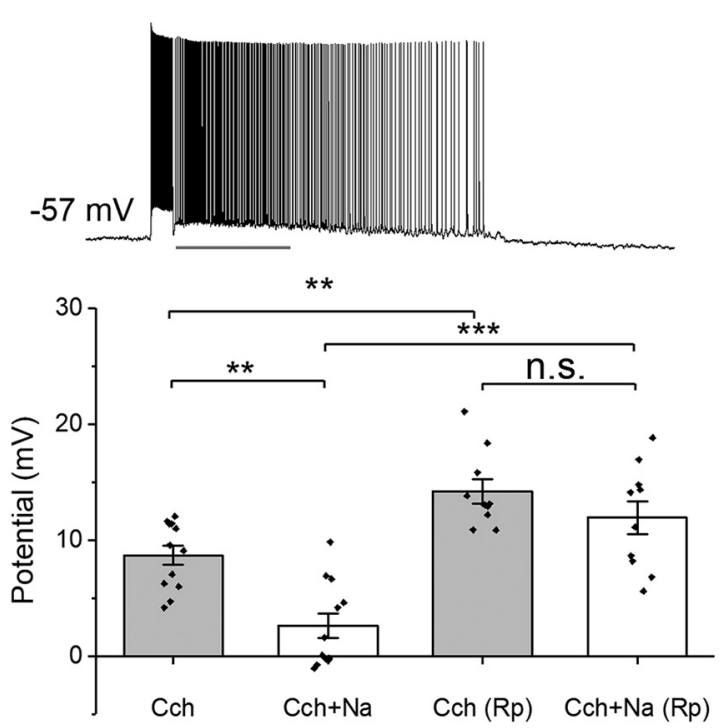

Cch + Forskolin (Rp)
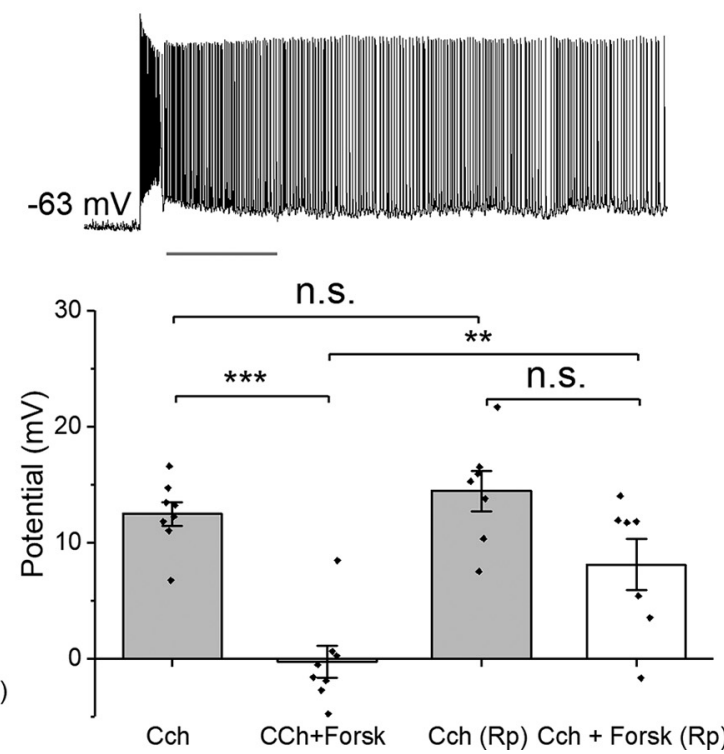

Figure 4. Inhibition of PKA by Rp-cAMPS blocks the NA and forskolin mediated reduction of persistent firing. $\boldsymbol{A}$, Representative traces of the effect of Rp-cAMPS on the NA-mediated inhibition of the cholinergic persistent firing. $\boldsymbol{B}$, Poststimulus frequency (left) and poststimulus potential (right) comparison with two-way repeated-measures ANOVA followed by Tukey's post hoc test. The first two columns show measurements without Rp-cAMPS from previous experiments. $\boldsymbol{C}$, Representative traces of the effect of RpCAMPS on the forskolin-mediated inhibition of the cholinergic persistent firing. $\boldsymbol{D}$, Poststimulus frequency (left) and poststimulus potential (right) comparison with two-way repeated-measures ANOVA followed by Tukey's post hoc test.

(Anderson and Strowbridge, 2014). This interpretation was in line with the decreased IR we observed in NA, which could be caused by the opening of GABAergic receptors. To gain insight into this, we used the same SBs as in Zhang et al. (2013), which demonstrated facilitated persistent firing by NA in PFC neurons. However, in the presence of the SBs, IR was still reduced and persistent firing was suppressed by NA. Based on these, we suggest that changes in synaptic transmission were not the main cause of persistent firing suppression in our study.

Another possibility is that the elevation of CAMP has modulated the hyperpolarization-activated cyclic nucleotide-gated $(\mathrm{HCN})$ channels. In the PFC, adrenergic stimulation of $\alpha 2$ receptors improved working memory performance by suppressing $\mathrm{HCN}$ channels through cAMP downregulation (Wang et al., 2007). This is in line with facilitated persistent firing in the PFC neurons under 
A

Cch

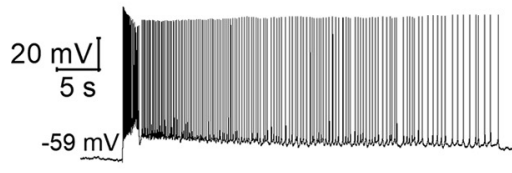

C Cch + ICl118551

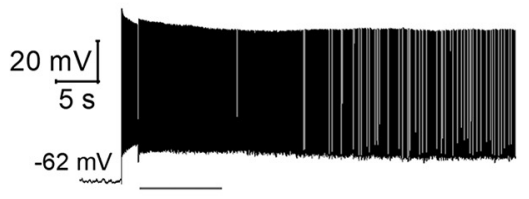

E

Cch

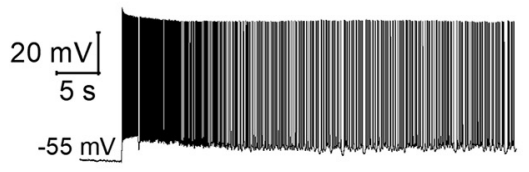

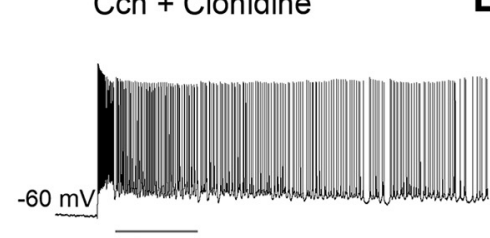

Cch + Clonidine

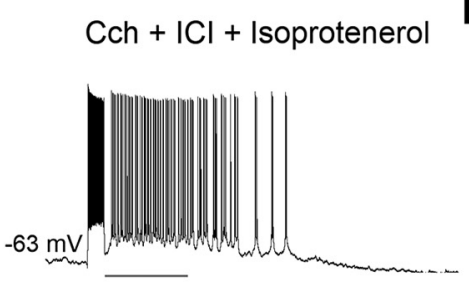

D

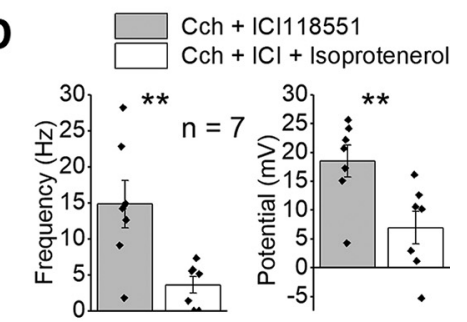

$\mathbf{F}$ Cch + Isoprotenerol

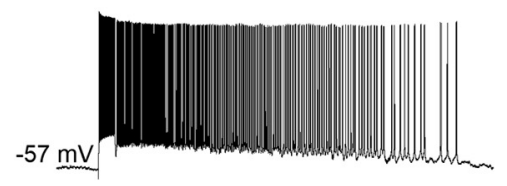

B
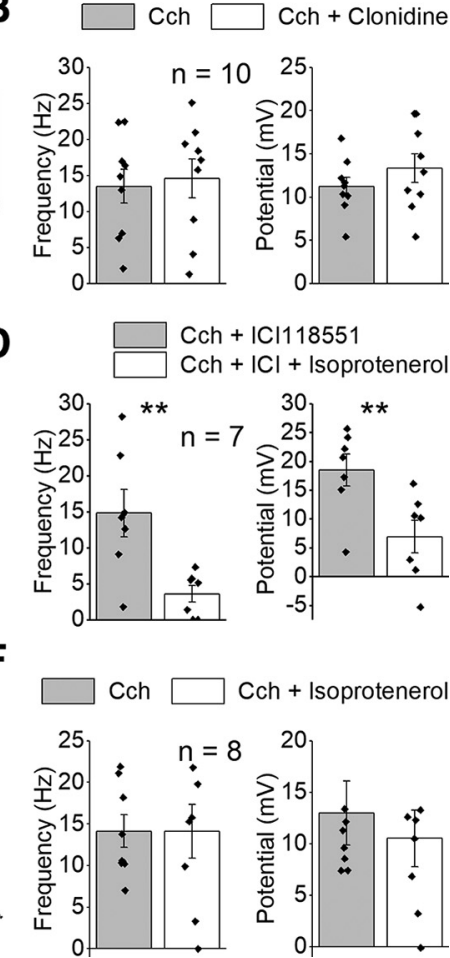

Cch + Isoprotenerol

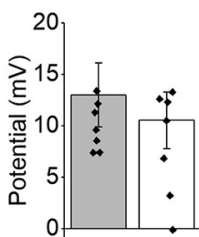

Figure 5. Roles of NA receptor subtypes in suppression of persistent firing. $\boldsymbol{A}$, Representative traces of the effect of clonidine on the cholinergic persistent firing. $\boldsymbol{B}$, Poststimulus frequency (left) and poststimulus potential (right) in Cch (gray) and Cch and clonidine (white). $\boldsymbol{C}$, Representative traces of the effect of $\beta 2$ (inhibited by ICl) versus $\beta 1$ and $\beta 3$ adrenergic receptors (activated by isoprotenerol in the presence of $\mathrm{ICl}$ ) on the cholinergic persistent firing. $\boldsymbol{D}$, Poststimulus frequency (left) and poststimulus potential (right) in a cocktail of Cch and ICI (gray) and in a cocktail of Cch, ICI and ISO (white). $\boldsymbol{E}$, Representative traces of the effect of $\beta$-receptor stimulation by isoprotenerol. $\boldsymbol{F}$, Poststimulus frequency (left) and poststimulus potential (right) in (gray) and Cch and ISO (white).

the blockade of HCN channels (Zhang et al., 2013). This mechanism might, however, not be involved in the suppression of persistent firing in our study because the sag potential, which indicates the amount of HCN current, was rather reduced by NA, suggesting a reduction, if any, of $\mathrm{HCN}$ current. In addition, $\alpha 2$ receptor agonist clonidine did not reduce the sag potential in our study. This could be because (1) the cAMP levels were already low because of Cch, and $\alpha 2$ activation could not further reduce the cAMP level; (2) modulation of HCN channels by CAMP is pronounced in young but is weak in adult animals in the hippocampus (Surges et al., 2006); and (3) the $\alpha 2$ receptor does not modulate the $\mathrm{HCN}$ channels because co-localization of the $\alpha 2$ receptor with the HCN channels, which is reported in the PFC (Wang et al., 2007), does not occur in the hippocampal CA1 pyramidal cells.

In addition, we cannot completely exclude the possibility that mGluR is involved in the suppression of persistent firing by NA. Similarly to Cch, mGluRs activate the $G_{q}$ (group 1) and $G_{i}$ (groups 2 and 3) pathways. When Cch is not present, NA-induced mGluR activation could play a role in modulating persistent firing as was the case in Zhang et al. (2013). However, in the presence of Cch as in our study, $G_{i}$ and $G_{q}$ are already highly activated, and an additional activation of the same $G_{i}$ and $G_{q}$ through mGluRs, if exists, could be marginal. This point has been tested by Zhang et al. (2013) by applying the mGluR blocker MPEP on persistent firing induced by $\mathrm{Cch}$, and they showed no change of persistent firing, indicating that the role of mGluR in persistent firing is limited when Cch is present. In contrast, when mGluRs are the main activator of the $G_{q}$ and $G_{i}$ pathways, NA may have a similar suppressive effect on persistent firing in the hippocampus. This view is supported by the suppression of mGluR-induced "plateau potential" and persistent firing by CAMP and PKA in the hippocampus and PFC (Sidiropoulou et al., 2009; El-Hassar et al., 2011).

\section{Suppressed persistent firing as a possible cellular mechanism of impaired working memory in high NA levels}

Roles of cholinergic receptor activation on persistent firing supported by intrinsic cellular mechanisms have been studied intensively in vitro (for review, see Major and Tank, 2004; Yoshida et al., 2012). Similarly to these prior studies, persistent firing was observed under cholinergic receptor activation in our experiment in hippocampal pyramidal CA1 cells in mice. This is in line with the supportive role of cholinergic activation on working memory (Kaneko and Thompson, 1997; Weiss et al., 2000). In addition, we have shown that cholinergically-induced persistent firing is suppressed by NA. In line with these 
results are the detrimental effects of high concentrations of NA on working memory (Arnsten, 2009; Roozendaal and McGaugh, 2011). Together, these observations indicate that both supportive (cholinergic) and detrimental (NA) modulations on working memory are in agreement with the cellular level modulation of PF, which is a possible cellular correlate of working memory.

Interestingly, persistent firing in our study was suppressed by $\beta 1 / 3$ receptors activation (Fig. $5 D$ ), while the use of general $\beta$ receptor agonist did not alter the response (Fig. $5 E$ ), suggesting that receptor subtypes have different effects on persistent firing. Traditionally, it has been believed that the actions of different $\beta$ receptors were identical, all activating the $\mathrm{G}_{\mathrm{s}}$ cascade. However, recent studies have suggested that $\beta 2$ receptors might act through different mechanisms than $\beta 1$, possibly by activating the $G_{i}$ cascade in addition to the $G_{s}$ cascade (Hall, 2004; Schutsky et al., 2011a,b). Since $G_{i}$ cascade counteract the action of $\mathrm{G}_{\mathrm{s}}$ cascade by decreasing cAMP levels, unclear effect of the general $\beta$ receptor agonist (Fig. $5 E$ ) could have been resulted from this action of $\beta 2$ receptors. Interestingly, the role of $\beta$ receptors in working memory was tested using generic agonists or antagonists, resulting in no apparent effect on this cognitive function (Arnsten et al., 1999). On the other hand, the specific activation of $\beta 1$ receptors has been shown to impair working memory, while the activation of $\beta 2$ has improved it (Ramos et al., 2005, 2008). Therefore, modulations of persistent firing and working memory agree with each other at the level of receptor subtypes in this case.

Our data using Rp-cAMPS and forskolin further suggested that the suppression of persistent firing was through cAMP upregulation, which can be induced by the activation of the $\mathrm{G}_{\mathrm{s}}$ cascade. Interestingly, multiple studies have indicated that increased cAMP levels impair working memory, while a reduction of cAMP levels improves it (Taylor et al., 1999; Ramos et al., 2003; Runyan et al., 2005). Moreover, increased cAMP reduced persistent firing in vivo during working memory tasks (Vijayraghavan et al., 2007; Wang et al., 2007). It is relevant to note that Rp-cAMPS has been tested in vivo in monkeys during an oculomotor delayed response working memory task (Vijayraghavan et al., 2007). In this study, Rp-cAMPS rescued D1 receptor mediated reduction of neural firing while an application of Rp-cAMPS alone increased the neuronal firing (Vijayraghavan et al., 2007). The rescue effect of Rp-cAMPS is in line with the suppressive roles of cAMP on persistent firing observed in our study. In addition, increased neural activity by the application of RpcAMPS in vivo is in line with the increased depolarization during persistent firing we observed in our study (Fig. 4B). In summary, $\mathrm{G}_{\mathrm{s}}$-mediated cAMP upregulation seems to be detrimental for both working memory and persistent firing, while $\mathrm{G}_{\mathrm{i}}$-mediated cAMP downregulation seems to support both working memory and persistent firing.

\section{Supportive role of moderate levels of NA on working memory}

In contrast to the detrimental effect of high levels of NA, it has been proposed that moderate concentrations of NA aid working memory through the $\alpha 2$ receptors because of relatively high affinity of NA to the $\alpha 2$ receptors (Arnsten and $\mathrm{Li}, 2005)$. In fact, working memory is facilitated by the $\alpha 2$ receptor activation in several studies (Jäkälä et al., 1999; Li et al., 1999; Birnbaum et al., 2000; Ma et al., 2003; Arnsten and Li, 2005). In the present study, we tested two doses of NA (5 and $10 \mu \mathrm{m}$ ); however, we did not observe facilitative effect of NA on persistent firing either with or without cholinergic agonist Cch. The lack of facilitative effect of NA on persistent firing could be because the two concentrations tested were both high doses equivalent to situations of stress, where $\beta 1 / 3$ receptors were active in addition to the $\alpha 2$ receptors, masking the positive effect of the $\alpha 2$ receptors. However, our experiment with the $\alpha 2$ receptor agonist indicates that there is no room for facilitation of persistent firing through $\alpha 2$ receptor activation at least in the presence of cholinergic agonist, meaning that in this condition, even a lower concentration of NA would not have facilitated persistent firing. The $\alpha 2$ receptor activates the $G_{i}$ cascade, which decreases CAMP levels. One possibility is that $\mathrm{Cch}$ at the concentration we used already decreased cAMP levels to a minimum through $G_{i}$ activation and therefore additional activation of the $\alpha 2$ receptors could not lower the cAMP levels further. In contrast to our study, in the rat PFC, application of NA $(10 \mu \mathrm{M})$ enhanced persistent firing with or without the cholinergic agonist Cch (Zhang et al., 2013). In their study, the persistent firing facilitation was mediated by a combination of $\alpha 1$ and $\alpha 2$ receptors, and no regulation was observed by the $\beta$ receptor activation. While the direction of modulation of persistent firing by NA is opposite from our study, the effect of cAMP level is consistent in both studies. While increased cAMP (through $\beta$ receptors) suppressed persistent firing in our study, a decreased cAMP (through $\alpha 2$ receptors) facilitated persistent firing in Zhang et al. (2013). Therefore, the opposite effect of NA could be caused by activation of different receptor subtypes in these studies, possibly because of different affinities or expression density between the hippocampus and PFC. Although data available on these issues is limited, it has been reported that the $\beta 3$ receptors are expressed more in the hippocampus than in the cortex, while $\alpha 2$ and $\beta 1$ receptors are similarly expressed in these areas in rats (McCune et al., 1993; Nicholas et al., 1993a,b; Summers et al., 1995). Inhibitory effect of NA in our study might be linked to a stronger activation of $\mathrm{G}_{\mathrm{s}}$ and $\mathrm{CAMP}$ upregulation through $\beta 3$ receptors in the hippocampal neurons.

In conclusion, working memory impairment and compromised persistent firing have often been attributed to a reduced recurrent synaptic excitation (Wang, 2001; Arnsten, 2011). For example, it is proposed that activation of $\mathrm{HCN}$ channels and SK channels at dendritic terminals attenuates synaptic currents and reduce persistent spiking under cAMP elevation (Wang et al., 2007, 2011). On the other hand, our study together with recent studies (Sidiropoulou et al., 2009; El-Hassar et al., 2011) support the idea that cAMP may modulate working memory through direct inhibition of the neuronal ability to support persistent firing, possibly through the modulation of CAN/TRPC current.

Impaired working memory because of high levels of cAMP may also be involved in normal aging, schizophrenia 
and traumatic brain injury in addition to high stress conditions (Arnsten, 2011; Wang et al., 2011; Kobori et al., 2015). In support of this view, knocking down the disrupted in schizophrenia 1 (DISC1) protein (a protein that participates in cAMP catabolism) results in a decrease of the TRPC current in rat PFC neurons (El-Hassar et al., 2014). In addition, an infusion of Rp-cAMPS in traumatic brain injury or aged rats with working memory deficits, improves the performance on those tasks (Ramos et al., 2003; Kobori et al., 2015). Therefore, the mechanism of suppression of intrinsic persistent firing we present here might be relevant to working memory impairment in different conditions such as aging, traumatic brain injury and schizophrenia as well.

\section{References}

Anderson RW, Strowbridge BW (2014) Regulation of persistent activity in hippocampal mossy cells by inhibitory synaptic potentials. Learn Mem 21:263-271.

Arboit A, Reboreda A, Yoshida M (2020) Involvement of TRPC4 and 5 channels in persistent firing in hippocampal CA1 pyramidal cells. Cells 9:365.

Arnsten AFT (2009) Stress signalling pathways that impair prefrontal cortex structure and function. Nat Rev Neurosci 10:410-422.

Arnsten AFT (2011) Catecholamine influences on dorsolateral prefrontal cortical networks. Biol Psychiatry 69:e89-e99.

Arnsten AFT, Li BM (2005) Neurobiology of executive functions: catecholamine influences on prefrontal cortical functions. Biol Psychiatry 57:1377-1384.

Arnsten AFT, Mathew R, Ubriani R, Taylor JR, Li BM (1999) $\alpha-1$ Noradrenergic receptor stimulation impairs prefrontal cortical cognitive function. Biol Psychiatry 45:26-31.

Arnsten AFT, Wang MJ, Paspalas CD (2012) Neuromodulation of thought: flexibilities and vulnerabilities in prefrontal cortical network synapses. Neuron 76:223-239.

Barch DM, Ceaser A (2012) Cognition in schizophrenia: core psychological and neural mechanisms. Trends Cogn Sci 16:27-34.

Benardo LS, Prince DA (1982) Cholinergic excitation of mammalian hippocampal pyramidal cells. Brain Res 249:315-331.

Birnbaum SG, Podell DM, Arnsten AFT (2000) Noradrenergic alpha-2 receptor agonists reverse working memory deficits induced by the anxiogenic drug, FG7142, in rats. Pharmacol Biochem Behav 67:397-403.

Bremner JD, Krystal JH, Southwick SM, Charney DS (1996) Noradrenergic mechanisms in stress and anxiety: I. Preclinical studies. Synapse 23:28-38.

Bukalo O, Fentrop N, Lee AYW, Salmen B, Law JWS, Wotjak CT, Schweizer M, Dityatev A, Schachner M (2004) Conditional ablation of the neural cell adhesion molecule reduces precision of spatial learning, long-term potentiation, and depression in the CA1 subfield of mouse hippocampus. J Neurosci 24:1565-1577.

Colombo M, Gross CG (1994) Responses of inferior temporal cortex and hippocampal neurons during delayed matching to sample in monkeys (Macaca fascicularis). Behav Neurosci 108:443-455.

Dash PK, Moore AN, Kobori N, Runyan JD (2007) Molecular activity underlying working memory. Learn Mem 14:554-563.

Diamond DM, Ingersoll N, Fleshner M, Rose GM (1996) Psychological stress impairs spatial working memory: relevance to electrophysiological studies of hippocampal function. Behav Neurosci 110:661672.

Egorov AV, Hamam BN, Fransén E, Hasselmo ME, Alonso AA (2002) Graded persistent activity in entorhinal cortex neurons. Nature 420:173-178.

El-Hassar L, Hagenston AM, D'Angelo LB, Yeckel MF (2011) Metabotropic glutamate receptors regulate hippocampal CA1 pyramidal neuron excitability via $\mathrm{Ca} 2+$ wave-dependent activation of SK and TRPC channels. J Physiol 589:3211-3229.
El-Hassar L, Simen AA, Duque A, Patel KD, Kaczmarek LK, Arnsten AFT, Yeckel MF (2014) Disrupted in schizophrenia 1 modulates medial prefrontal cortex pyramidal neuron activity through cAMP regulation of transient receptor potential $\mathrm{C}$ and small-conductance K+ channels. Biol Psychiatry 76:476-485.

Fraser DD, MacVicar BA (1996) Cholinergic-dependent plateau potential in hippocampal CA1 pyramidal neurons. I Neurosci 16:4113-4128.

Funahashi S, Bruce CJ, Goldman-Rakic PS (1989) Mnemonic coding of visual space in the monkey's dorsolateral prefrontal cortex. $J$ Neurophysiol 61:331-349.

Goldman-Rakic PS (1995) Cellular basis of working memory. Neuron 14:477-485.

Haj-Dahmane S, Andrade R (1998) Ionic mechanism of the slow afterdepolarization induced by muscarinic receptor activation in rat prefrontal cortex. J Neurophysiol 80:1197-1210.

Hall RA (2004) $\beta$-Adrenergic receptors and their interacting proteins. Semin Cell Dev Biol 15:281-288.

Hampson RE, Deadwyler SA (2003) Temporal firing characteristics and the strategic role of subicular neurons in short-term memory. Hippocampus 13:529-541.

Jäkälä P, Sirviö J, Riekkinen M, Koivisto E, Kejonen K, Vanhanen M, Riekkinen P Jr (1999) Guanfacine and clonidine, alpha2-agonists, improve paired associates learning, but not delayed matching to sample, in humans. Neuropsychopharmacology 20:119-130.

Jochems A, Yoshida M (2013) Persistent firing supported by an intrinsic cellular mechanism in hippocampal CA3 pyramidal cells. Eur J Neurosci 38:2250-2259.

Kamiński J, Sullivan S, Chung JM, Ross IB, Mamelak AN, Rutishauser U (2017) Persistently active neurons in human medial frontal and medial temporal lobe support working memory. Nat Neurosci 20:590-601.

Kaneko T, Thompson RF (1997) Disruption of trace conditioning of the nictitating membrane response in rabbits by central cholinergic blockade. Psychopharmacology (Berl) 131:161-166.

Kawaguchi Y, Shindou T (1998) Noradrenergic excitation and inhibition of GABAergic cell types in rat frontal cortex. J Neurosci 18:6963-6976.

Knauer B, Jochems A, Valero-Aracama MJ, Yoshida M (2013) Longlasting intrinsic persistent firing in rat CA1 pyramidal cells: a possible mechanism for active maintenance of memory. Hippocampus 23:820-831.

Kobori N, Moore AN, Dash PK (2015) Altered regulation of protein kinase a activity in the medial prefrontal cortex of normal and braininjured animals actively engaged in a working memory task. $J$ Neurotrauma 32:139-148.

Li BM, Mao ZM, Wang M, Mei ZT (1999) Alpha-2 adrenergic modulation of prefrontal cortical neuronal activity related to spatial working memory in monkeys. Neuropsychopharmacology 21:601-610.

Ma CL, Qi XL, Peng JY, Li BM (2003) Selective deficit in no-go performance induced by blockade of prefrontal cortical alpha 2-adrenoceptors in monkeys. Neuroreport 14:1013-1016.

Madison DV, Nicoll RA (1982) Noradrenaline blocks accommodation of pyramidal cell discharge in the hippocampus. Nature 299:636638.

Major G, Tank D (2004) Persistent neural activity: prevalence and mechanisms. Curr Opin Neurobiol 14:675-684.

McCune SK, Voigt MM, Hill JM (1993) Expression of multiple alpha adrenergic receptor subtype messenger RNAs in the adult rat brain. Neuroscience 57:143-151.

Millar JK, Pickard BS, Mackie S, James R, Christie S, Buchanan SR, Malloy MP, Chubb JE, Huston E, Baillie GS, Thomson PA, Hill EV, Brandon NJ, Rain JC, Camargo LM, Whiting PJ, Houslay MD, Blackwood DHR, Muir WJ, Porteous DJ (2005) DISC1 and PDE4B are interacting genetic factors in schizophrenia that regulate cAMP signaling. Science 310:1187-1191.

Navaroli VL, Zhao Y, Boguszewski P, Brown TH (2012) Muscarinic receptor activation enables persistent firing in pyramidal neurons from superficial layers of dorsal perirhinal cortex. Hippocampus 22:1392-1404. 
Nicholas AP, Pieribone VA, Hökfelt T (1993a) Cellular localization of messenger RNA for beta- 1 and beta- 2 adrenergic receptors in rat brain: an in situ hybridization study. Neuroscience 56:1023-1039.

Nicholas AP, Pieribone V, Hökfelt T (1993b) Distributions of mRNAs for alpha-2 adrenergic receptor subtypes in rat brain: an in situ hybridization study. J Comp Neurol 328:575-594.

Partridge LD, Swandulla D, Müller TH (1990) Modulation of calciumactivated non-specific cation currents by cyclic AMP-dependent phosphorylation in neurones of helix. J Physiol 429:131-145.

Qin S, Hermans EJ, van Marle HJF, Luo J, Fernández G (2009) Acute psychological stress reduces working memory-related activity in the dorsolateral prefrontal cortex. Biol Psychiatry 66:25-32.

Ramos BP, Birnbaum SG, Lindenmayer I, Newton SS, Duman RS, Arnsten AFT (2003) Dysregulation of protein kinase a signaling in the aged prefrontal cortex: new strategy for treating age-related cognitive decline. Neuron 40:835-845.

Ramos BP, Colgan L, Nou E, Ovadia S, Wilson SR, Arnsten AFT (2005) The beta-1 adrenergic antagonist, betaxolol, improves working memory performance in rats and monkeys. Biol Psychiatry 58:894-900.

Ramos BP, Colgan LA, Nou E, Arnsten AFT (2008) Beta2 Adrenergic agonist, clenbuterol, enhances working memory performance in aging animals. Neurobiol Aging 29:1060-1069.

Reboreda A, Jiménez-Díaz L, Navarro-López JD (2011) TRP channels and neural persistent activity. Adv Exp Med Biol 704:323-339.

Reboreda A, Theissen FM, Valero-Aracama MJ, Arboit A, Corbu MA, Yoshida M (2018) Do TRPC channels support working memory? Comparing modulations of TRPC channels and working memory through G-protein coupled receptors and neuromodulators. Behav Brain Res 354:64-83.

Roozendaal B, McGaugh JL (2011) Memory modulation. Behav Neurosci 125:797-824.

Runyan JD, Moore AN, Dash PK (2005) A role for prefrontal calciumsensitive protein phosphatase and kinase activities in working memory. Learn Mem 12:103-110.

Schoofs D, Preuss D, Wolf OT (2008) Psychosocial stress induces working memory impairments in an $n$-back paradigm. Psychoneuroendocrinology 33:643-653.

Schutsky K, Ouyang M, Castelino CB, Zhang L, Thomas SA (2011a) Stress and glucocorticoids impair memory retrieval via $\beta_{2}$-adrenergic, $G_{i / o}$-coupled suppression of cAMP signaling. J Neurosci $31: 14172-14181$

Schutsky K, Ouyang M, Thomas SA (2011b) Xamoterol impairs hippocampus-dependent emotional memory retrieval via Gi/ocoupled $\beta 2$-adrenergic signaling. Learn Mem 18:598-604.

Sessler FM, Liu W, Kirifides ML, Mouradian RD, Lin RCS, Waterhouse BD (1995) Noradrenergic enhancement of GABA-induced input resistance changes in layer $V$ regular spiking pyramidal neurons of rat somatosensory cortex. Brain Res 675:171-182.

Sidiropoulou K, Lu F-M, Fowler MA, Xiao R, Phillips C, Ozkan ED, Zhu MX, White FJ, Cooper DC (2009) Dopamine modulates an mGluR5-mediated depolarization underlying prefrontal persistent activity. Nat Neurosci 12:190-199.
Summers RJ, Papaioannou M, Harris S, Evans BA (1995) Expression of $\beta 3$-adrenoceptor mRNA in rat brain. Br J Pharmacol 116:25472548.

Sung TS, Jeon JP, Kim BJ, Hong C, Kim SY, Kim J, Jeon JH, Kim HJ, Suh CK, Kim SJ, So I (2011) Molecular determinants of PKAdependent inhibition of TRPC5 channel. Am J Physiol Cell Physiol 301:C823-C832.

Surges R, Brewster AL, Bender RA, Beck H, Feuerstein TJ, Baram TZ (2006) Regulated expression of HCN channels and cAMP levels shape the properties of the $\mathrm{h}$ current in developing rat hippocampus. Eur J Neurosci 24:94-104.

Tahvildari B, Alonso AA, Bourque CW (2008) Ionic basis of ON and OFF persistent activity in layer III lateral entorhinal cortical principal neurons. J Neurophysiol 99:2006-2011.

Taylor JR, Birnbaum S, Ubriani R, Arnsten AF (1999) Activation of cAMP-dependent protein kinase $A$ in prefrontal cortex impairs working memory performance. J Neurosci 19:RC23.

Valero-Aracama MJ, Sauvage MM, Yoshida M (2015) Environmental enrichment modulates intrinsic cellular excitability of hippocampal CA1 pyramidal cells in a housing duration and anatomical location-dependent manner. Behavioural Brain Res 292:209-218.

Vijayraghavan S, Wang M, Birnbaum SG, Williams GV, Arnsten AFT (2007) Inverted-U dopamine D1 receptor actions on prefrontal neurons engaged in working memory. Nat Neurosci 10:376-384.

Wang M, Ramos BP, Paspalas CD, Shu Y, Simen A, Duque A, Vijayraghavan S, Brennan A, Dudley A, Nou E, Mazer JA, McCormick DA, Arnsten AFT (2007) Alpha2A-adrenoceptors strengthen working memory networks by inhibiting CAMP-HCN channel signaling in prefrontal cortex. Cell 129:397-410.

Wang M, Gamo NJ, Yang Y, Jin LE, Wang XJ, Laubach M, Mazer JA, Lee D, Arnsten AFT (2011) Neuronal basis of age-related working memory decline. Nature 476:210-213.

Wang XJ (2001) Synaptic reverberation underlying mnemonic persistent activity. Trends Neurosci 24:455-463.

Weiss C, Preston AR, Oh MM, Schwarz RD, Welty D, Disterhoft JF (2000) The M1 muscarinic agonist $\mathrm{Cl}-1017$ facilitates trace eyeblink conditioning in aging rabbits and increases the excitability of CA1 pyramidal neurons. J Neurosci 20:783-790.

Yan HD, Villalobos C, Andrade R (2009) TRPC channels mediate a muscarinic receptor-induced afterdepolarization in cerebral cortex. J Neurosci 29:10038-10046.

Yoshida M, Knauer B, Jochems A (2012) Cholinergic modulation of the CAN current may adjust neural dynamics for active memory maintenance, spatial navigation and time-compressed replay. Front Neural Circuits 6:10

Zhang Z, Reboreda A, Alonso A, Barker PA, Séguéla P (2011) TRPC channels underlie cholinergic plateau potentials and persistent activity in entorhinal cortex. Hippocampus 21:386-397.

Zhang Z, Cordeiro Matos S, Jego S, Adamantidis A, Séguéla P (2013) Norepinephrine drives persistent activity in prefrontal cortex via synergistic $\alpha 1$ and $\alpha 2$ adrenoceptors. PLoS One 8:e66122. 